which have been cut off as a result of war conditions. Until recently, also, the Exhibition Galleries have been closed to the general public, although facilities have been accorded for visits by organized parties, of which there have been many applications. On the other hand, the demands for loans of films, lantern slides and the provision of lecturers have, as might be expected, increased.

After fifty years, one is entitled to ask how far can the Institute claim to have fulfilled the objects with which it was founded. Certainly in some respects it has not entirely fulfilled them; thus it has never been able to play the predominant part as a centre for the organization of intra-Imperial activities which was originally foreseen for it. No doubt this is partly the result of the preoccupation of those responsible for its destinies in its early days with the immediate difficulties of finance and management. It is true that the Institute has attracted to itself a number of related activities which although they are operated as independent units still come within its general ambit; as examples may be men. tioned the office of the Trade Commissioner for Burma and the investigational work carried out by the London Advisory Committee for Rubber Research. It is also true that a much larger number of new developments have come into being, covering a wider field, which are operated independently of the Institute; examples of these are the Imperial Agricultural Bureaux and the Imperial Economic Committee; the Dominions, India and many of the Colonial Dependencies have also set up information agencies and bureaux which operate independently of the Institute. There is free and friendly collabora- tion between the Instritute and all these organizations, but it seems reasonable to suppose that the original intention, when the Institute was first envisaged, was that all activities of this nature should come within the $x$ gis of the Institute.

It is a matter for speculation whether the course which events have actually taken may not in the long run have been preferable to that originally envisaged, and in any event the position is now firmly established.

On the other hand, the Institute has unquestionably amply fulfilled the role which was laid down for it as a centre for the investigation of raw materials and the collection and dissemination of information concerning the products of the Empire, while its publicity and educational work within the limits of the resources available could scarcely be bettered, although there is probably scope for their considerable further extension provided the necessary finance could be provided.

On balance, therefore, it must be admitted that the Institute has gone far towards achieving the expectations which were entertained when it was founded; it occupies a unique position and renders services of great value in many directions which would otherwise be unprovided. It may indeed be said that, as it stands to-day, it is a not unworthy memorial of the great Queen whose golden jubilee it was designed to commemorate. It is to be hoped that during the next fifty years its progress will continue unimpeded, and that in the post-war era there will occur the further expansion of its activities and utility for which abundant opportunity exists.

\title{
OBITUARIES
}

Mr. E. Heron-Allen, F.R.S.

EDward Heron-Allen, who was born in London on December 17, 1861, was educated at Harrow, where his natural aptitude for microscope work was roused. Necessity, however, led him to study law, and in 1884 he was admitted a solicitor. He followed his profession very successfully for some years, but his inclinations lay in other directions and were always asserting themselves. Ultimately he was in a position to follow them completely, and thenceforth the Foraminifera received his main attention.

Heron-Allen had, however, already published a "Prolegomena towards the Study of the Chalk Foraminifera ..." in 1894, but from about 1908 onwards for the next twenty-five years the results of his researches flowed fairly regularly. Throughout the greater part of that time, Heron-Allen's work was done in close association with Mr. Arthur Earland. Their papers covered not only British foraminiferal faunas (for example, Selsey, the North Sea, west of Scotland, Clare Island, Plymouth) but also those of far distant parts of the world, such as the Kerimba Archipelago and areas visited by the Terra Nove and Discovery expeditions. Nor were older faunas ignored, and publications on the Foraminifera of the Eocene of Biarritz (1919) and the Miocene of Moorabool, Victoria, Australia (1924) ensued. The room in the Zoological Department of the British Museum (Natural History) allotted to the two partners became the store-house of a magnificent collection of Foraminifera, to which Heron-Allen added other historic collections. It also housed a unique library concerning the group, a library which contains rare works and original MSS. and drawings of Foraminifera. Heron-Allen generously presented these to the Museum some years ago. He was elected a fellow of the Royal Society in 1919, was a member of numerous other societies, and during 1916-18 was president of the Royal-Microscopical Society.

Although most of his work was on systematics, Heron-Allen was interested in other aspects of the Foraminifera, and he read a paper on their bionomics to the Royal Society in 1915. For him the Foraminifera were essentially living creatures, and he epitomized this in a favourite lecture of his (and he was a fascinating lecturer) on purpose and intelligence in the Foraminifera. In his approach to systematics Heron-Allen was a faithful disciple of H. B. Brady, and his classification of the Foraminifera was based on the one used in that author's memorable Challenger Report. If, for a long time, he was impatient of the many new genera and species erected by oil-palæontologists, it was because so many of them, especially at first, were the product of immature work and scant knowledge of variation within even well-known and abundant species. He was also initially sceptical of the claims by oil-palæontologists of the value of the Foraminifera in the search for oil, though, when the basis of their work was explained to him, his attitude became much more sympathetic to them and to the changes in foraminiferal nomenclature that have been made. 
But Heron-Allen was a man of great vitality which expended itself in more than one way. For many years he lived at Selsey and he wrote on its geology, archæology and history; for example, "Selsey Bill: Historic and Pre-Historic", published in 1911. $\mathrm{He}$ was no mean horticulturalist, and in 1928 was president of the National Auricula Society. The violin was a life-long attraction, and so early as 1882 he had published an essay on violin-making. 'Witty, cultured and well read, Heron-Allen was an entertaining conversationalist, and he frequently pointed his remarks by an apt quotation from one of the many languages, classical and modern, which he knew. Of these, Persian held pride of place, and in 1898 he published a literal translation of the Bodleian MS. of the "Rubéiyat of Omar Khayyám", and in 1899 what was really a defence of the accuracy of Fitzgerald's well-known poetical translation. His many-sided character even found a place for palmistry and circus-riding while on a visit (1886-89) to America! He was district commissioner of Boy Scouts for South-west Sussex during 1910-19, while in 1918 his talents were used in the Staff Intelligence Department of the War Office.

As a friend Heron-Allen was staunch and generous, embarrassingly so sometimes; as an opponent, he was tough and unyielding. He typified in his person and character much of the late Victorian era, and he was a connoisseur in all that he took up. He was twice married. The tragic death of his younger daughter some years ago, when she was on the threshold of a promising zoological career, was a blow from which he never really recovered. Pneumonia took toll of his strength in the autumn of 1941, but his gay, fighting spirit never gave in. He died at his home at Selsey on March 28, and is survived by his wife and one daughter.

\section{H. Dighton Thomas.}

\section{NEWS and VIEWS}

\section{Hydro-Electric Development in Scotland}

THIs is an opportune time for any information about rainfall and run off in the area comprised in the Hydro-Electric Development (Scotland) Bill now before Parliament (see NATURF, Feb. 13, pp. 177 and 187). Before us we have two reports and a memorandum by Captain W. N. McClean, founder and director of the River Flow Records Organization. The first report is on "River Flow Records of the Ness Basin 1929-1942". It describes the measurements made on the rivers feeding into Loch Ness and on the River Ness which drains the Loch. The report shows that the author has had to carry out his work with very limited means for equipment, maintenance and labour-clearly much of the latter has been voluntary. As the local authorities of Inverness have now agreed to maintain the author's records of the Ness Basin, their value is obvious. The second report, published in January last, is on "The Water Resources of Loch Quoich". This Loch feeds Loch Garry, which in turn feeds Loch Oich-a small loch near Loch Ness on the Caledonian Canal. Capt. McClean regards Loch Quoich as one of the sources of possible water-power and one of the gems of Scottish scenery. From records over some twelve years, he has no doubt that 15,000 kilowatts continuously can be developed here without considerable cost in dam construction for storage.

In his memorandum, Capt. McClean emphasizes the need for an Inland Water Survey of Great Britain to obtain correct hydrological data. He is not satis. fied that rainfall statistics suffice; also he pleads for water records to be removed from all sectional interests. "There are," he says, "certain figures in the year-book ["Surface Water Yearbook" of the Inland Water Survey Committee appointed in 1935 by the Ministry of Health] which are grossly and intentionally wrong, and they would seriously affect the figuring out of the capacity of Power Schemes in an important area of Scotland. Other figures are just missing, because it might be inconvenient to divulge them." Enough has been said to give an idea of Capt. W. N. McClean's work and of the views he has formed. From faets disclosed in the Cooper
Report, it follows that, in face of indifference and discouragement, pioneers like Capt. McClean needed much faith to carry on in all the vagaries of Scottish weather.

\section{Avalanche Research in Switzerland}

DURING the War of 1914-18 the number of avalanche fatalities among the armies in alpine regions was very high; in the period between the two wars, the influx of winter visitors to the Alps was followed by an alarming increase in accidents due to inexperience in snow-craft. It became obvious that a proper study of snow and avalanches was needed. There followed the private research work of individuals in many parts of Central Europe, who in turn were succeeded by more elaborately organized groups. In 1934 the Swiss authorities inaugurated a small research laboratory on the Weissfluhjoch close to the upper end of one of the Davos funiculars at a height of $8,500 \mathrm{ft}$. Under the direction of Dr. H. Bader, a crystallographer, and Dr. M. Haefeli, a civil engineer, much valuable work was carried out ranging from the purely scientific to the severely practical. The former has given us a 'great deal of new knowledge of the structure and behaviour of ice crystals, such as their rearrangement into regular order under stress with its clearly defined metal. lurgical analogy. Among the latter were such tests as the reaction of different types of snow to varying meteorological conditions and the resulting tendency to increase or decrease avalanche danger. The drawing together of the many threads of research followed and the results, combined with the investi. gations of practical men in the mountains, have been of the greatest value in bringing about a closer understanding of, and so mitigating, avalanche dangers. An excellent publication of some 340 pages was produced in 1939 recounting the field and laboratory work up to the end of 1938 , and subsequent publications have also appeared.

Originally the governing body of the Weissfluhjoch station. was the Swiss Commission for Snow and Avalanche Research under the chairmanship of the head of the Federal Forestry Department and working 